\title{
SPORTUOJANČIŲ IR RIZIKOS GRUPĖS PAAUGLIŲ PATIRIAMŲ IR JŲ PAČIŲ VYKDOMŲ PATYČIŲ DAŽNUMAS
}

\author{
Ilona Tilindienė, Giedrẻ Rastauskienė, Irena Valantinienė, Nijolė Lagūnavičienė
} Lietuvos kūno kultūros akademija, Kaunas, Lietuva

\begin{abstract}
Ilona Tilindienė. Socialinių mokslų daktarè. Lietuvos kūno kultūros akademijos Sporto pedagogikos ir psichologijos katedros docentė.
\end{abstract} Mokslinių tyrimų kryptis - socialinè edukologija.

\section{SANTRAUKA}

Lietuvos ir užsienio mokslininkai teigia, kad mokyklose agresyvumo, tyčiojimosi mastas vis didëja ir, kaip j̇rodyta empiriniais tyrimais (Povilaitis, Valiukevičiūtè, 2004; Christian, Kashiwagi, 2007; Carlson, Cornell, 2008; Zaborskis, Vareikiene, 2008 ir kt.), yra vaiku, kurie nuolatos patiria bendraamžiu patyčias mokykloje.

Šiame straipsnyje analizuojamas 5-10 kl. sportuojančiu ir rizikos grupès paaugliu patiriamu patyčiu dažnumas amžiaus, lyties aspektais. Tyrimo tikslas - atskleisti 5-10 kl. sportuojančiu ir rizikos grupés paaugliu patiriamu ir ju pačiu vykdomu patyčiu dažnuma.

Tyrimo objektas - 5-10 kl. sportuojančiu ir rizikos grupés paaugliu patiriamu ir ju pačiu vykdomu patyčiu dažnumas.

Tyrimo uždaviniai: 1) nustatyti 5-10 kl. sportuojančiu ir rizikos grupés paaugliu patiriamu patyčiu dažnuma lyties ir amžiaus aspektais; 2) ivvertinti tiriamuju tyčiojimosi iš bendraamžiu dažnuma lyties ir amžiaus aspektais; 3) atskleisti asmens patiriamu patyčiu ir jo paties tyčiojimosi iš kitu bendraamžiu dažnumo priklausomybę.

2008 metais buvo apklausti 296 Kauno miesto mokyklu sportuojantys ir rizikos grupés paaugliai. Tiriamiesiems buvo pateiktas klausimynas, parengtas remiantis Didžiosios Britanijos Jorko miesto Patyčiu klausimynu moksleiviams, o gauti duomenys interpretuoti naudojant neparametrinę statistika.

Nustatyta, kad patyčiu dažnumas nepriklauso nuo lyties — tiek merginos, tiek vaikinai patiria analogiška patyčiu dažnuma. Sportavimo ir amžiaus veiksniai mažina patiriamu patyčiu dažnuma — sportininkai (tiek merginos, tiek vaikinai) patiria patyčias rečiau nei rizikos grupès paaugliai, o vyresniuju (8-10 kl.) klasiu paaugliai patyčias patiria rečiau nei jaunesniuju (5-7 kl.).

Rizikos grupès paaugliai dažniau tyčiojasi iš kitu vaiku, nei sportuojantieji. Tyčiojimosi dažnumas iš kitu taip pat priklauso nuo lyties ir amžiaus veiksniu. Merginos teigia, kad jos rečiau tyčiojasi iš bendraamžiu nei vaikinai, o vyresni (8-10 kl.) paaugliai - rečiau nei jaunesni (5-7 kl.).

Analizuojant asmens patiriamu patyčiu ir jo paties tyčiojimosi iš bendraamžiu dažnumo raiška nustatyta silpna tiesine šiu reiškiniu priklausomybè 5-7 klasèse ir sportuojančiu paaugliu grupèse.

Raktažodžiai: patyčiu dažnumas, popamokinè veikla, agresyvus elgesys.

\section{IVADAS}

[ ietuvos ir užsienio mokslininkai nurodo, kad mokyklose agresyvumo, tyčiojimosi mastas vis didejja ir, kaip irodyta empiriniais tyrimais (Povilaitis, Valiukevičiūtè, 2004; Zaborskis, Vareikienè, 2008; Christian, Kashiwagi, 2007; Carlson, Cornell, 2008 ir kt.), yra vaikų, kurie nuolat patiria bendraamžių patyčias mokykloje.
Patyčias patiriančių ir iš kitų besityčiojančių moksleivių skaičius Lietuvos mokyklose yra didesnis negu kitose Europos šalyse (Zaborskis ir kt., 2005). Remiantis 1994-2002 m. tarptautinio moksleiviu sveikatos ir gyvensenos tyrimo duomenimis, Lietuvoje kas trečias $11-15$ metu moksleivis 2-3 kartus per mėnesi arba dažniau patiria kitų moksleivių patyčias. Beveik tiek pat 
moksleivių patys tyčiojasi (Zaborskis ir kt., 2005) iš bendraamžių.

Literatūroje galima rasti daug tyrimų, susijusių su patyčių reiškiniu. Analizuojamas patyčiu dažnumas. Amerikiečių mokslininkai (Wilson, 2006; Bullying by the numbers, 2007) nurodo, kad tyčiojimąsi patiria vienas iš triju 6-10 kl. moksleivių; Vokietijoje nuolat patyčias patiria maždaug $8 \%$ vaiku, 22\% - patys jas inicijuoja (Wolke et al., 2001 - cit iš Targamadzès, Valeckienès, 2007). Lietuvoje, kaip ir buvo minèta, patyčias patiria nuo 50 iki $70 \%$ vaikų (Povilaitis, Valiukevičiūtè, 2004; Zaborskis ir kt., 2005; Zaborskis, Vareikienè, 2008).

Mokslininkai gilinasi ir i patyčiu formu raiška. Lietuvių autoriai išskiria tokias patyčiu formas: tiesiogines (vaikas atvirai puolamas, užgauliojamas savo bendraamžiu) ir netiesiogines (asmuo skaudinamas nenaudojant tiesioginès agresijos). Pagal tai, kokia agresija yra naudojama vaiko atžvilgiu, patyčios skirstomos i žodines, fizines, sudètines (Povilaitis, Valiukevičiūtè, 2006). Užsienio tyrejai (Wilson, 2006; San Antonio, Salzfass, 2007) tyčiojimąsi skirsto i fizini (mušimą, spardyma), žodini (pravardžiavimą, erzinimą) ir psichologini (socialini atskyrimą, prievartą, paskalų skleidimą).

Šiuo metu užsienyje ir Lietuvoje dažnai minima nauja tyčiojimosi forma - tyčiojimasis internetu - tai telefonų ir kompiuterių naudojimas (elektroniniu paštu siunčiami vaizdai ir žinutès, varginant ar gąsdinant kitus). Mokiniai, patyre tyčiojimąsi internetu, labiau linkę praleidinèti pamokas, blogiau mokytis, yra prislègti (Wolfsberg, 2006). Škotijoje mokslininkai, ištyrę 100 šeimų iš Nacionalinès autistų bendruomenès, išsiaiškino, kad net 38\% (28\% mergaičiu ir 10\% berniukų) autistu vaiku buvo tyčiojimosi internetu aukos (Teachers not trained to handle bullying, claims committe, 2007).

Atliekami tyrimai, irodantys negatyvu patyčiu poveiki asmenybès psichikos sveikatos ir elgesio problemu atsiradimui. M. F. Van der Wal, C. A. M. De Wit ir R. A. Hirasing (2003) tyrimo duomenimis, ir berniukai, ir mergaitès, iš kurių yra tyčiojamasi, dažnai patiria depresiją, juos kamuoja mintys apie savižudybę. Paaugliai, tapę patyčiu aukomis ir (arba) patys tyčiojęsi iš kitu, turèjo didesnę savižudiškų ketinimų galimybę nei tie, kurie nebuvo to patyrę. L. C. Fleming, K. H. Jacobsen (2009) teigimu, patyčios yra stipriai susijusios su depresijos simptomais, ir tai būdingiau mergaitèms.
A. Zaborskis ir I. Vareikienè (2008) nustatè, kad mokykloje pasireiškusios patyčios susijusios su blogesniu moksleiviu savo sveikatos vertinimu, menkesniu pasitenkinimu gyvenimu ir dažnais galvos, skrandžio, nugaros skausmais, liūdesiu, irzlumu, nervine įtampa, nemiga, galvos svaigimu, silpnumu. Nustatytos sąsajos priklausė nuo tiriamujų lyties ir patyčiu pobūdžio. Tyčiojęsi iš kitų paaugliai buvo linkę rūkyti, vartoti svaigiuosius gèrimus ir narkotines medžiagas. Taip pat išryškèjo, kad jaunuoliai, po vieną kriminalini nusikaltimą ivykdę iki 24 metu, 6-9 klasėse buvo identifikuoti kaip priekabiautojai (tyčiotojai), $40 \%$ iš jų iki 30 metų amžiaus buvo teisti tris ir daugiau kartų. Suaugę tyčiotojai pasityčiojimą perneša ir i šeimą smurtaudami (Bullying by the numbers, 2007). Tuo tarpu vaikai-aukos dažnai tampa suaugusiais-aukomis ir leidžia tyčiotis iš savęs darbo vietoje, šeimoje (Fritz, 2006; Root, 2006).

Taigi pastaraisiais metais jaunuz žmonių agresyvaus elgesio tyrimams skiriama itin daug dèmesio: analizuojama patyčių intensyvumas, formos, lyčiu skirtumai, pasekmès asmenybės psichosocialinei sveikatai (McGuckin, 2006; Wilson, 2006; San Antonio, 2007; Targamadzè, Valeckiené, 2007; Zaborskis, Vareikienė, 2008; Fleming, Jacobsen, 2009 ir kt.), ieškoma veiksmingų būdų ir priemonių, kaip spręsti šią problemą.

Deja, mokslinejje literatūroje pasigendama tyrimų, kurių metu būtų nagrinėjama sportavimo ir patyčiu priklausomybė (pvz., kaip sportavimas susijęs su agresijos raiška, patyčių prevencija ir pan.). Juolab kad mokslinejje literatūroje nuolatos diskutuojama, kaip sportas veikia asmenybès socialinius igūdžius, saviugdą, nuo kuriu priklauso individo elgesys aplinkoje (Šniras, Malinauskas, 2005; Yoneyama, Rigby, 2006 ir kt.). Taip pat nèra daug tyrimų, kuriais būtų analizuojama, kaip priklausymo rizikos grupei veiksnys (ji lydintis agresyvus, asocialus elgesys) veikia tyčiojimosi procesą. Taigi įdomu patyrinèti šias dvi specifines grupes tyčiojimosi raiškos aspektu, nes kai kurie autoriai (Ivanauskienè, 2005; Bruyn, Cillessen, 2006; Dunn et al., 2008) nurodo, kad tiek sportuojantys, tiek rizikos grupes paaugliai yra padidintos agresijos (tik vieni — prosocialia, kiti — asocialia forma), taip pat išskirtinio statuso (tiek pozityvaus, tiek negatyvaus) turejjimu bendraamžių grupejje, ir tai gali paskatinti būti patyčių iniciatoriais arba nevykdyti patyčių; patiems tapti patyčiu aukomis arba jų išvengti. Visa tai paskatino iškelti tyrimo tiksla - atskleisti 5-10 kl. sportuojančių ir rizi- 


\begin{tabular}{|l|c|c|c|}
\hline \multicolumn{1}{|c|}{ Tiriamųjų grupès } & Merginos & Vaikinai & Iš viso \\
\hline Sportuojantys paaugliai & 127 & 114 & 241 \\
\hline Rizikos grupès paaugliai & 35 & 20 & 55 \\
\hline Iš viso & 162 & 134 & 296 \\
\hline
\end{tabular}

Lentelè. Socialinès-demografinès tyrimo imties apibūdinimas

kos grupés paauglių patiriamų ir jų pačių vykdomų patyčių dažnumą.

Tyrimo objektas $-5-10 \mathrm{kl}$. sportuojančiu ir rizikos grupès paauglių patiriamų ir jų pačiu vykdomų patyčių dažnumas.

Tyrimo uždaviniai: 1) nustatyti $5-10 \mathrm{kl}$. sportuojančiu ir rizikos grupès paaugliu patiriamų patyčiu dažnumą lyties ir amžiaus aspektais; 2) ivvertinti tiriamujų tyčiojimosi iš bendraamžiu dažnumą lyties ir amžiaus aspektais; 3) atskleisti asmens patiriamų patyčių ir jo paties tyčiojimosi is kitų bendraamžių dažnumo priklausomybę.

\section{TYRIMO METODIKA}

Tiriamiesiems buvo pateiktas adaptuotas klausimynas, parengtas remiantis Didžiosios Britanijos Jorko miesto Patyčiu klausimynu moksleiviams (prieiga internetu http://www.state.de.us/attgen/ main_page/teachers/bullquesti.htm), kuri sudarè 11 uždaro ir atviro tipo klausimu. Kiekvienas klausimas turejjo nuo 2 iki 10 atsakymo variantų. Tiriamiesiems reikejo pasirinkti vieną, kai kur kelis atsakymo variantus. Klausimynas adaptuotas atlikus žvalgomaji tyrimą Kauno sporto mokykloje. Buvo ištirta dvidešimt $12-17$ metų mokinių. Jiems pateikti Patyčiu klausimyne esantys klausimai, kuriu atsakymo variantus turejo pasirinkti. Antrą kartą mokiniai apklausti po dviejų savaičių, gautas $81 \%$ duomenu stabilumas.

Anketoje pateikti klausimai suskirstyti $\mathfrak{i}$ dvi grupes - viena klausimu grupe rodo tiriamuju patiriamų, kita - inicijuojamų patyčių raišką. Anketoje pateikti tokie klausimai, kaip antai: ar is Tavęs tyčiojamasi mokyloje; kas iš Tavęs tyčiojasi; kur iš Tavęs buvo tyčiojamasi; ar tyčiojiesi iš kitu vaiku mokykloje pats; tyčiojiesi vienas ar su kitais moksleiviais ir pan.

Tyrimo metodai - mokslinès literatūros analizè ir anketavimas. Gautiems duomenims apdoroti naudota SPSS programa. Lyginamų grupių imtys buvo parenkamos atsižvelgiant i W. C. VanVoorhis ir L. B. Morgan (2001) statistinio tyrimo taisykles. Ryšio tarp kintamujų analizei atlikti taikème neparametrinès statistikos asociacinès analizès $\chi^{2}$ metodą. Patiriamu patyčiu skalès vertès buvo suvienodintos su pačių tiriamujų vykdomų patyčiu skalès vertemis, perkoduojant patiriamų patyčiu reikšmę labai dažnai i dažnai. Šių skalių ryšio stiprumas ivertintas Gamma koeficientu (Паниотто, Максименко, 2003). Tyčiojimosi skirtumai laikyti statistiškai patikimais, esant ne didesnei nei $5 \%$ paklaidai $(\mathrm{p}<0,05)$.

Tiriamieji ir tyrimo organizavimas. Apklausai, kuri buvo atliekama 2008 metais, atsitiktinès patogiosios atrakos būdu atrinkti 296 Kauno miesto mokyklų 5-10 kl. (12-16 m.) paaugliai. Tiriamieji suskirstyti $\mathfrak{i}$ dvi grupes: pirma grupe sportuojantys paaugliai, antra - rizikos grupès vaikai. Sportuojančiais asmenimis laikème tuos, kurie mažiausiai po du kartus per savaitę lanko(-è) pratybas sporto mokyklose ar klubuose ir sportuoja(-avo) ne mažiau kaip vienerius metus, dalyvauja(-avo) varžybose. Rizikos grupès vaikais laikème tuos, kurie gyvena asocialiose, nedarniose arba nepilnose šeimose, patiria psichologinę, fizinę ar seksualinę prievartą, gyvena ypač sunkiomis materialinėmis sąlygomis, taip pat agresyvius, bendraamžių atstumtus vaikus ir tuos, kurie yra padarę smulkių prasižengimų ar nusikaltimų, turinčius pedagoginių ar psichologinių problemu.

Sportuojantys paaugliai apklausti Kauno m. sporto mokyklose. Tyrimas vykdytas kūno kultūros pamokų metu, iš anksto suderinus su mokyklos vadovybe ir dalyko mokytoju. Rizikos grupès vaikai apklausti vaikų dienos centruose pratybų metu, taip pat gavus vadovybès sutikimą (žr. lent.).

\section{REZULTATAI}

Patiriamų patyčių dažnumas sportuojančiuju grupeje yra mažesnis $(4,10,41,45 \%)$ ir skiriasi nuo rizikos grupés paauglių $(2,6,53$ ir $40 \%)$. Patyčiu paplitimas tarp nesportuojančių ir rizikos grupès paauglių reikšmingai nesiskiria $\left(\chi^{2}=8,52(3)\right.$; $\mathrm{p}>0,05)$ (1 pav.).

Didèjant tiriamujjų amžiui, patyčių dažnis mažèja $\left(\chi^{2}=23,7(3) ; p=0,000\right)(2$ pav.). 47\% vyresniu mokinių teigia, kad niekada nepatiria patyčiu arba jas patiria kartais (41\%), su tuo sutinka 27 ir $64 \%$ jaunesniu (5-7 kl.) mokinių.

Tyrinejjant patyčių dažnumą lyties atžvilgiu galima teigti, kad tiek merginos, tiek vaikinai patiria analogišką patyčių dažnumą. Kas dešimta mergina ir kas dešimtas vaikinas patiria dažnas 
1 pav. Patyčių dažnumo sklaida tarp sportuojančių ir rizikos grupių paauglių

2 pav. Patyčių dažnumo sklaida tarp 5-7 ir 8-10 kl. paauglių
3 pav. Patyčių dažnumo sklaida tarp merginų ir vaikinų
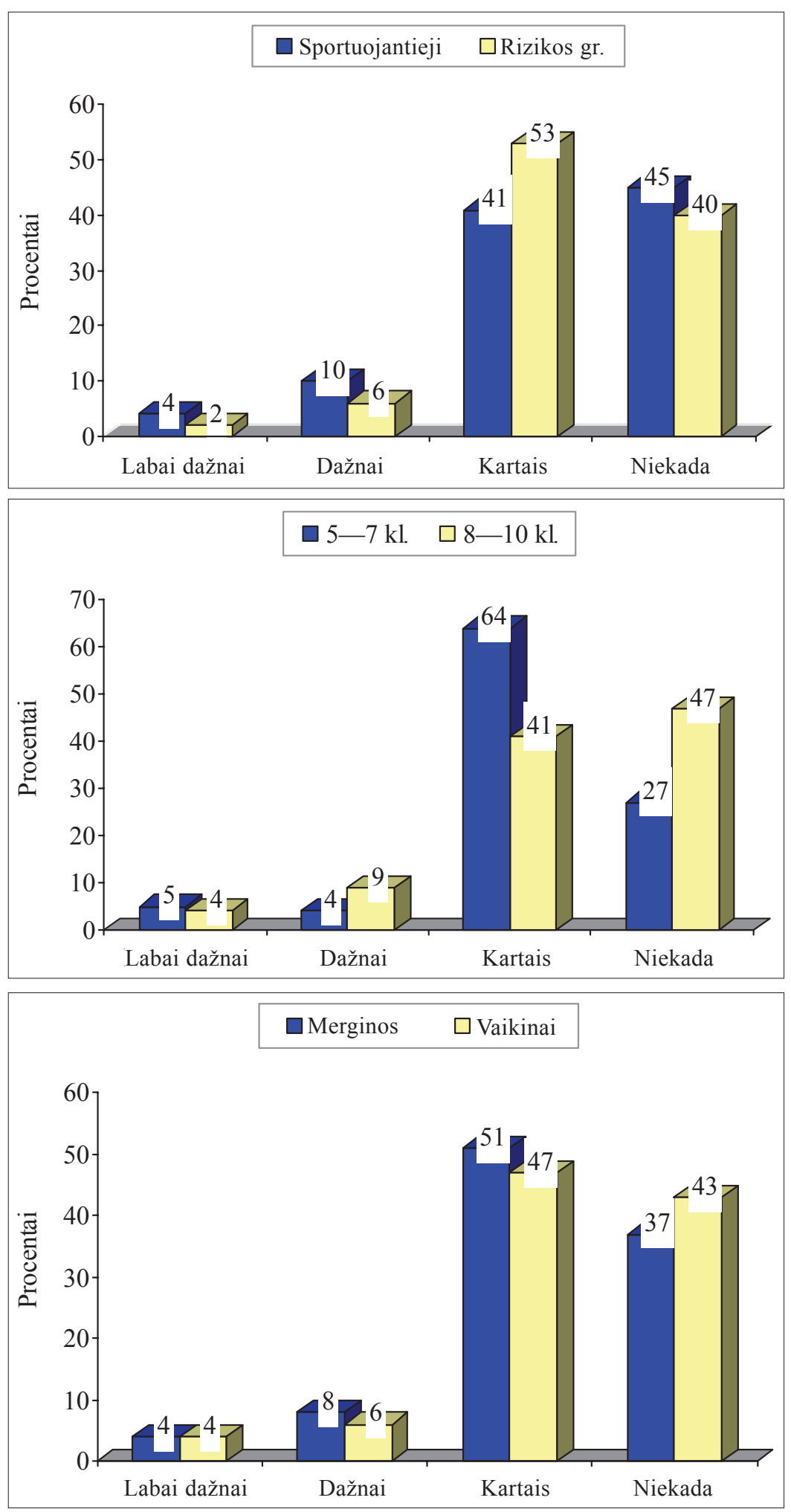

ir labai dažnas patyčias, pusė merginu ir puse vaikinų teigia jas patiriantys kartais. Tai būdinga abiem tiriamuju grupèm $\left(\chi^{2}=6,81(3) ; p>0,05\right)$ (3 pav.).

Nagrinejjant pačiu paauglių iš kitu tyčiojimosi dažnumą matyti, kad rizkos grupès paaugliai labiau nei sportuojantys prisipažista besityčiojantys iš kitų: $65 \%$ jų teigia, kad tai daro kartais, $17 \%$ — dažnai. Tuo tarpu $45 \%$ sportuojančių tiriamujų nurodo nie- kada nesityčioję iš kitų vaikų arba tyčiojęsi kartais $(42 \%)\left(\chi^{2}=12,56(2) ; p=<0,01\right)(4$ pav. $)$.

Tyčiojimąsi iš kitų bendramoksliu mažai lemia lyties ir amžiaus veiksniai. Merginos teigia, kad jos rečiau tyčiojasi iš kitu bendraamžių nei vaikinai $\left(\chi^{2}=17,1(2) ; p=0,000\right)(5$ pav.), o vyresni $(8-10 \mathrm{kl}$.) paaugliai kiek rečiau tyčiojasi nei jaunesni $\left(5-7 \mathrm{kl}\right.$.) $\left(\chi^{2}=10,0(2) ; \mathrm{p}=0,007\right)$ (6 pav.). 

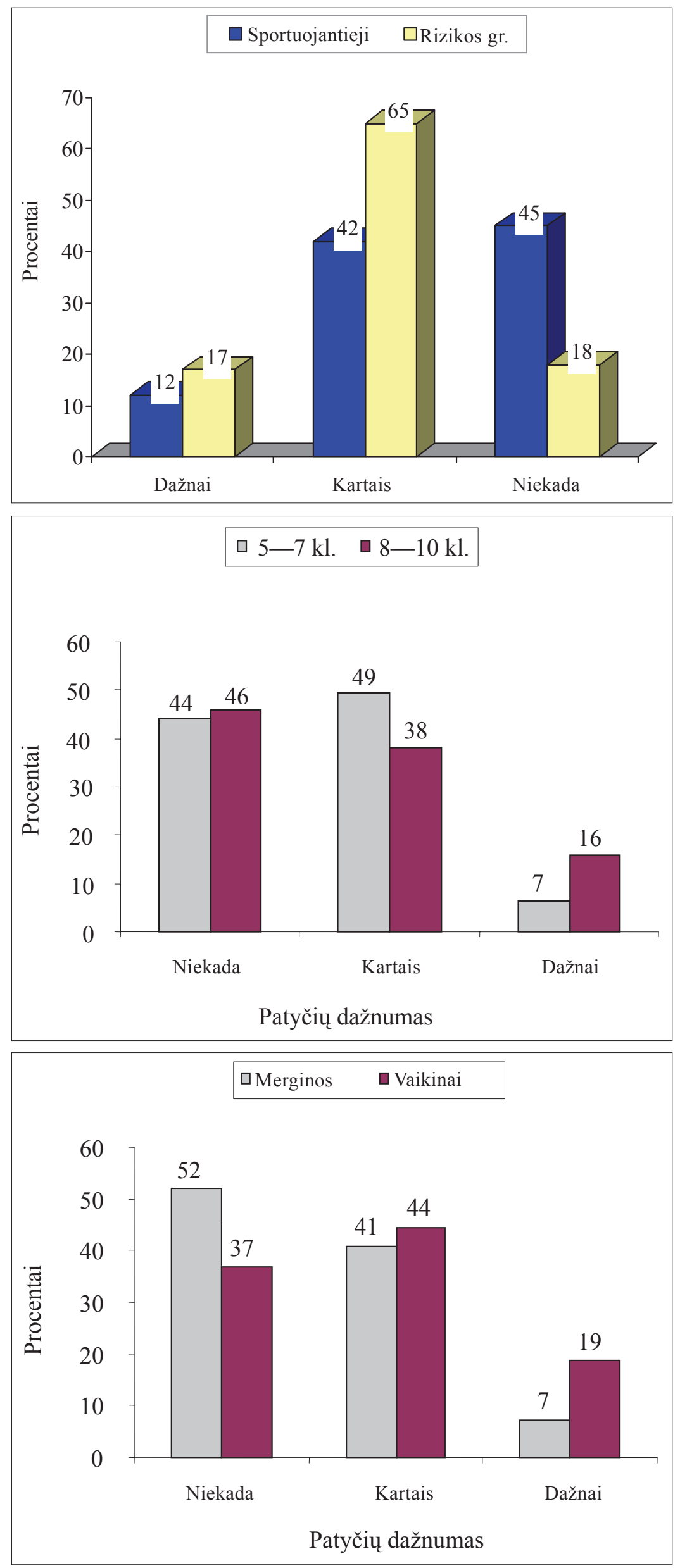

4 pav. Paauglių tyčiojimosi iš kitų dažnumo sklaida

5pav. Paauglių tyčiojimosi iš kitų dažnumo sklaida lyties aspektu

6 pav. Paauglių tyčiojimosi iš kitų dažnumo sklaida amžiaus aspektu 
Tyrimo duomenys leidžia teigti, kad egzistuoja silpna tiesine priklausomybe tarp asmens patiriamų patyčių dažnumo ir jo paties tyčiojimosi iš kitų bendraamžių jaunesnių (5-7 kl.) paaugliu grupeje $(\gamma=0,293 ; p=0,035)$. Ši silpna tiesinè priklausomybė taip pat pastebèta sportuojančiuju grupeje $(\gamma=0,183 ; p=0,048)$.

\section{REZULTATUQ APTARIMAS}

Sportuojantys paaugliai patiria mažiau patyčių ir rečiau jas inicijuoja nei rizikos grupès ju bendraamžiai. Vadinasi, sportuojančiu paauglių požiūris i save yra geresnis ir jie labiau pasitiki savimi nei nesportuojantys ar rizikos grupès bendraamžiai (Tilindienè, Miškinis, 2003). J. A. Dake, J. H. Price, S. K. Telljohann (2003) taip pat nustatė reikšmingą ryši tarp tyčiojimosi ir savęs vertinimo, kurį dažnai lemia vaiko socialinis statusas, psichologinè ir socialinè gerovè. Sportuojantys paaugliai save vertina pagal pasiekimus ir pagal tai bando pelnyti pripažinimą, pagarbą tarp bendraamžių, kartu susilaukti ir mažiau patyčių (Hagger et al., 2005). Tuo tarpu rizikos grupès paaugliai pripažinimo socialinio statuso grupeje siekia demonstruodami agresyvu elgesi, ir tai sukelia bendraamžių agresyvumą, patyčias ju pačių atžvilgiu (Bruyn, Cillessen, 2006).

Mūsų tyrimu nustatyta, kad didējant tiriamujų amžiui patyčių dažnis mažèja. Tai patvirtina A. Zaborskio, L. Cirtautienès ir N. Žemaitienès $2005 \mathrm{~m}$. tyrimo duomenys. A. Zaborskis ir I. Vareikienè $2008 \mathrm{~m}$. taip pat nustatė: nepriklausomai nuo lyties jaunesnio amžiaus moksleiviai dažniau nei vyresni buvo tapę patyčių aukomis; didèjant amžiui, moksleiviai vis mažiau tyčiojasi iš kitų.

Tiriant patyčių dažnumą lyties atžvilgiu galima teigti, kad tiek merginos, tiek vaikinai jas patiria panašiai. Taigi lyties veiksnys nelemia patiriamų patyčių dažnumo. Tai neatitinka A. Zaborskio, L. Cirtautienès ir N. Žemaitienès (2005) tyrimo duomenų, teigiančių, kad berniukai dažniau nei mergaitès patiria patyčias ir patys labiau linkę tyčiotis iš kitú. Visgi jau 2008 metais A. Zaborskis ir I. Vareikienè nustatè, kad vaikinai daug rečiau nei merginos tampa patyčių aukomis, tačiau dažniau yra linkę tyčiotis iš kitų.

Tyčiojimąsi iš kitų bendramokslių mažai lemia lyties ir amžiaus veiksniai. Merginos teigia, kad jos rečiau tyčiojasi iš bendraamžių nei vaikinai, o vyresni $(8-10 \mathrm{kl}$.) paaugliai kiek rečiau nei jaunesni $(5-7 \mathrm{kl}$.).
Kitų mokslininkų tyrimų rezultatai atskleidžia lyties skirtumus, susijusius su agresyviu elgesiu. Nurodoma, kad berniukai agresyvesni ir labiau priekabiauja nei mergaitès (Ivanauskienè, 2005; Zaborskis ir kt., 2005; Digelidis et al., 2006; Miller, 2007; San Antonio, Salzfass, 2007; Zaborskis, Vareikienè, 2008).

Visgi kai kurie mokslininkai (Eslea et al., 2004- cit. iš Zaborskis ir kt., 2005) nurodo, kad bręstantys paaugliai kuklesni ir labiau gedijasi, jei iš jų tyčiojamasi, todèl gali nepatvirtinti patirto tyčiojimosi, net jei apklausa anoniminè. Australijos tyrimo duomenimis, kai vaikai paauga, jie gèdijasi prisipažinti apie patirtas patyčias, todèl ir šio tyrimo duomenys gali būti netikslūs (cit. iš Zaborskis ir kt., 2005).

Egzistuoja silpna tiesinè priklausomybė tarp asmens patiriamų patyčių dažnumo ir jo paties tyčiojimosi iš kitų bendraamžių jaunesnių ( $5-7 \mathrm{kl}$.) paaugliu grupejje. Ši silpna tiesinè priklausomybe taip pat pastebèta sportuojančiuju grupejje. Tai atitinka tyrimų rezultatus, nurodančius, kad vaikai, iš kurių tyčiojasi, patys pradeda tyčiotis iš kitu (Dake et al., 2003; Ando et al., 2005; Povilaitis, Valiukevičiūtè, 2006; Yoneyama, Rigby, 2006; Miller, 2007).

\section{IŠVADOS}

1. Nagrinèjant paauglių patiriamų patyčių dažnumą 5-10 klasėse nustatyta, kad jis nepriklauso nuo lyties. Tiek merginos, tiek vaikinai patiria analogišką patyčių dažnumą. Sportavimo ir amžiaus veiksniai mažina patiriamu patyčiu dažnumą. Sportininkai (tiek merginos, tiek vaikinai) patiria patyčias rečiau nei rizikos grupès paaugliai, o vyresniuju ( 8 -10 kl.) klasiu paaugliai patyčias patiria rečiau nei jaunesniuju (5-7 kl.).

2. Rizikos grupès paaugliai dažniau tyčiojasi iš kitų vaikų nei sportuojantieji paaugliai. Tyčiojimosi dažnumas iš kitų taip pat priklauso nuo lyties ir amžiaus veiksnių. Merginos teigia, kad jos rečiau tyčiojasi iš kitų bendraamžių nei vaikinai, o vyresni (8-10 k1.) paaugliai — rečiau nei jaunesni (5-7 kl.).

3. Analizuojant asmens patiriamų patyčių ir jo paties tyčiojimosi iš kitų bendraamžių dažnumo raišką nustatyta silpna tiesinè šių reiškinių priklausomybė nuo amžiaus (5-7 klasėse) ir nuo popamokinès veiklos (sportuojančiu paaugliu grupèse). 


\section{LITERATŪRA}

Ando, M., Asakura, T., Simons-Morton, B. (2005). Psychosocial influences on physical, verbal, and indirect bullying among japanese early adolescents. Journal of Early Adolescence, 25 (3), 268-297.

Bernthal, M. J., Medway, F. J. (2005). An initial exploration into the psychological implications of adolescents involvement with professional wrestling. School Psychology International, 26 (2), 224-242.

Bruyn, E. H., Cillessen, A. H. N. (2006). Popularity in early adolescence: prosocial and antisocial subtypes. Journal of Adolescent Research, 21 (6), 607-627.

Bullying by the numbers (2007). Curriculum review, 01472453, Jan 46 (5).

Carlson, L. W., Cornell, D. G. (2008). Differences between persistent and desistent middle school bullies. School Psychology International, 29 (4), 442-45.

Christian, C., Kashiwagi, A. (2007). The wrong plan for schools? Newsweek (Atlantic Edition), 01637053, 1 / 15, 149 (3).

Dake, J. A., Price, J. H., Telljohann, S. K. (2003). The nature and extent of bullying at school. The Journal of School Health, 73 (5), 173-80

Digelidis, N., Boyatzi, A., Chatzigeorgiadis, A., Papaioannou, A. (2006). Aggressiveness, goal orientations and intrinsic motivation in physical education classes. Inquiries in Sport \& Physical Education, 4 (1), 57-68.

Dunn Causgrove, J., Dunn, J. G. H., Bayduza, A. (2008). Perceived athletic competence, sociometric status, and loneliness in elementary school children. Journal of Sport Behavior, 30 (3), 249-269.

Fleming, L. C., Jacobsen, K. H. (2009). Bullying and symptoms of depression in chilean middle school students. Journal of School Health, 79 (3), 130-137.

Fritz, G. K. (2006). Is your child or student a bully or a victim of bullying? Brown University Child \& Adolescent Behavior Letter, Jun 22 (6), 8.

Hagger, M. S., Biddle, S. J. H., Wang, C. K. J. (2005). Physical self-concept in adolescence: Generalizability of a multidimensional, hierarchical model across gender and grade. Educational and Psychological Measurement, 65 (2), 297-322.

Ivanauskienè, V. (2005). Paauglių požiūrio i savo klasės atstumtuosius ypatumai. Socialinis darbas, 4 (2), 78-83.

McGuckin, C., Lewis, C. A. (2006). Experiences of school bullying in Northern Ireland: Data from the life and times survey. Adolescence, 41 (162), 313-320.

Miller, K. E. (2007). Psychopathologic behavior: A consequence of bullying? American Family Physician, 1 / 15 , 75 (2), 252-257.

Povilaitis, R., Valiukevičiūtè, J. (2004). Apie priekabiavi$m q$. Vilnius: Multiplex.
Povilaitis, R., Valiukevičiūtè, J. (2006). Patyčiu prevencija mokyklose. Vilnius: Multiplex.

Root, T. (2006). Student / teacher partnerships can be the key to combat bullying. Educational Journal, 92, 7.

San Antonio, D. M., Salzfass, E. A. (2007). How we treat one another in school. Educational Leadership, 64 (8), $32-38$

Šniras, Š., Malinauskas, R. (2005). Moral skills of schoolchildren: Social behavior and personality. Society for Personality Research, 33 (4), 383-390.

Šukys, S. Jankauskienè, R. (2008). Mokinių sportavimo ir fizinio aktyvumo laisvalaikiu sasajos su psichosocialiniais, elgesio ir mokyklos veiksniais. Ugdymas. Küno kultūra. Sportas, 1 (68), 92-99.

Targamadzè, V., Valeckienė, Dž. (2007). Patyčių bendrojo lavinimo mokykloje samprata: priežasčiu, formu ir pasekmiu diskursas. Acta paedagogica Vilnensia, 19, $159-171$.

Teachers not trained to handle bullying, claims committe. (2007). Education, 3 (30), 1263-1272.

Tilindienè, I., Miškinis, K. (2003). Sporto komandų psichologinio klimato ir jose sportuojančiu paaugliu pasitikèjimo savimi sąsaja. Ugdymas. Küno kultūra. Sportas, 3 (48), 78 - 82

Van der Wal, M. F., De Wit, Cees, A. M., Hirasing, R. A. (2003). Psychosocial health among young victims and offenders of direct and indirect bullying. Pediatrics, 111 (6), 1312-1317.

Van Voorhis, W. C., Morgan, L. B. (2001). Statistical rules of thumb: What we don't want to forget about sample sizes. Psi Chi Journal of Undergraduate Research, 6 (4).

Wilson, A. (2006). The bully problems. World \& I, 21 (8), $136-141$.

Wolfsberg, J. S. (2006). Student safety from cyberbullies, in chat rooms, and in instant messaging. Education Digest, $72(2), 33-37$.

Yoneyama, S., Rigby, K. (2006). Bully / victim students \& clasroom climate. Youth Studies Australia, 25 (3), $34-41$.

Zaborskis, A., Cirtautienè, L., Žemaitienè, N. (2005). Moksleiviu patyčios Lietuvos mokyklose 1994-2002 m. Medicina, 41 (7), 614-621.

Zaborskis, A., Vareikienė, I. (2008). Patyčios mokykloje ir jų sąsajos su moksleivių sveikata bei gyvensena. Medicina, $44(3), 232-239$

Паниотто, В. И., Максименко, В. С. (2003). Количественные методы в соииологических исследованиях Киев. Prieiga internetu : http://www.ecsocman.edu.ru/db/ $\mathrm{msg} / 77144 . \mathrm{html}$ 


\title{
THE FREQUENCY OF EXPERIENCED BULLYING OF ATHLETES AND RISK GROUP ADOLESCENTS AND THEIR BULLYING AT COEVALS
}

\author{
Ilona Tilindienė, Giedrẻ Rastauskienė, Irena Valantinienė, Nijolė Lagūnavičienė \\ Lithuanian Academy of Physical Education, Kaunas, Lithuania
}

\begin{abstract}
Lithuanian and foreign scientists indicate that in the schools the scale of aggresiveness and bullying is growing and as it has been proved by the empirical research (Povilaitis, Valiukevičiūtè, 2004; Christian, Kashiwagi, 2007; Carlson, Cornell, 2008; Zaborskis, Vareikienė, 2008 and others) there are children, who constantly experience bullying by coevals at school.

This article analyzes athletes and at-risk adolescents from the 5-10th forms and their experienced bullying incidence in the age and gender aspects. The purpose of the survey was to disclose the frequency athletes and at-risk adolescents' experienced bullying and bullying carried out by themselves.

Research object was the frequency of 12-15 year-old athletes and risk group adolescents' experienced bullying and bullyings implemented by themselves.

Research tasks: 1) to identify the aspects of gender and age of athletes and at risk adolescents and their experienced bullying frequency; 2) to evaluate the influence of gender and age factors on the frequency of researched bullying at coevals; 3 ) to disclose the dependence of frequency between person's experienced bullyings and their bullying at other coevals.

296 athletes and at-risk adolescents from various Kaunas town schools participated in the interview, which was carried out in 2008. The subjects were given questionnaires, based on the British City of York school bullying questionnaire, and the data were interpreted using non-parametric statistics.

Analyzing the frequency of experienced bullyings among the 5-10th form adolescents, we determined that it did not depend on gender - girls and boys experienced the same frequency of bullyings. Sports and age factors lowered the frequency of experienced bullying - athletes (both girls and boys) experienced bullyings more seldom than risk-group adolescents and older adolescents experienced bullyings more seldom than younger adolescents.

We found that bullying did not depend on gender — both girls and boys experienced similar frequency of bullying. As for sport and age factors in reducing the frequency of bullying experienced, athletes (both girls and boys) suffered less bullying than of at-risk adolescents, and older adolecents suffered less bullying than younger adolescents.

Analyzing the frequency expression of persons' experienced bullyings and their bullying at other coevals, we determined low linear dependence of these expressions between age and after-school activities (in athletes adolescent groups).
\end{abstract}

Keywords: frequency of bullying, after-school activities, aggressive behavior.

Ilona Tilindienè

Lietuvos kūno kultūros akademija

(Lithuanian Academy of Physical Education)

Sporto g. 6, LT-44221 Kaunas

Lietuva (Lithuania)

Tel +37037209050

E-mail i.tilindiene@lkka.lt 